\title{
Limiting Procedural Rights During Police Interrogation in Terror Crimes: A Comparative Analysis of European and U.S. Laws and Suggestions to Turkish Law
}

\author{
Terör Suçlarında Polisin İfade Alması Sırasında Şüpheli Haklarının \\ Sınırlandırılması: Avrupa ve ABD Hukuklarının Karşılaştırmalı Analizi \\ ve Türk Hukukuna Öneriler
}

\section{Gülen SOYASLAN ${ }^{1}$ (1)}

${ }^{1}$ Dr., Adiyaman University Faculty of Economics and Administrative Sciences, Department of Public Administration, Adiyaman, Turkey

ORCID: G.S. 0000-0003-4725-1416

\section{ABSTRACT}

This article aims to contribute to Turkish counterterrorism law through a comparative law analysis on procedural rights in police interrogation. It compares the scope and roots of the right to counsel, the right to silence and the right to be notified of these rights in the U.S., the European Court of Human Rights (ECtHR) judgments and Turkey. Particularly, it scrutinizes the conditions under which these rights can be restricted in emergency circumstances and in cases when unscrupulous defense counsel aims to obstruct justice or further terrorism by abusing their communication with a terror suspect. Firstly, the article proposes that Turkey should establish a public safety exception to the right to counsel and the right to be informed of procedural rights when there is an urgent need to protect the life, liberty and bodily integrity of individuals. Secondly, it addresses a common problem stated by senior Turkish counterterrorism officials in interviews: defense counsel may be engaged with the terrorist organization of a suspect, coerce him to give a statement in a particular way, or facilitate information exchange. The article recommends that Turkey should enact an amendment allowing the replacement of unethical defense counsel with another lawyer through a magistrate judge order.

Keywords: The right to counsel, the right to be notified of procedural rights, public safety exception, the exclusion of defense counsel

Submitted: 07.01.2020 • Revision Requested: 01.04.2020 • Last Revision Received: 01.05.2020 • Accepted: 12.06.2020 •

Published Online: 00.00 .0000

Corresponding author: Gülen Soyaslan, E-mail: gsoyaslan@adiyaman.edu.tr; gulensoyaslan@gmail.com

Citation: Soyaslan, G. 'Limiting Procedural Rights During Police Interrogation in Terror Crimes: A Comparative Analysis of European and U.S. Laws and Suggestions to Turkish Law' (2020) 8(1) Ceza Hukuku ve Kriminoloji Dergisi-Journal of Penal Law and Criminology, 143. 


\section{Introduction}

Procedural rights serve as the protectors of individual self-esteem and autonomy as well as safeguards against the coercive nature of police questioning. They are significant for assuring a fair trial and the proper administration of justice. The procedural rights of suspects in custodial police interrogation are the right to counsel, the right to silence, and the right to be notified of these rights. This article explains the scope, legal groundings and limitation of these rights in the U.S. and European Court of Human Rights (ECtHR) jurisdictions as well as Turkey. Particularly, it scrutinizes the circumstances under which these rights can be restricted in terror cases to promote Turkey's counterterrorism efforts. It makes two proposals to Turkish law based on comparative law analyses as well as on interviews with Turkish counterterrorism officials.

The comparative law analyses are based on the U.S. Supreme Court and ECtHR judgments as well as on German law. Interviews were conducted by the author with Turkish security officials as well as judges and prosecutors with experience in terror cases. Eight counterterrorism officials, including four senior counterterrorism officers and two prosecutors and judges with considerable experience in terror cases, were interviewed in 2017 in Ankara. ${ }^{1}$ Their opinions were utilized as supporting arguments for the study.

The article is built upon two proposals to Turkish law. First, it proposes a public safety exception to the right to counsel and the right to be informed of procedural rights. According to Turkish law, the police are required to warn a suspect of his procedural rights. It is mandatory to provide counsel during custodial interrogation if the minimum statutory punishment of a crime is five years of imprisonment. A statement obtained without the presence of lawyer in custodial interrogation cannot be used as primary evidence in court if the defendant objects (Ceza Muhakemesi Kanunu [C.M.K.], 2004, art. 148-4, 150-3). Failure to remind procedural rights and provide defense counsel, with no exception, would result in a statement being regarded as illegally obtained and excluded at trial. However, there may be cases in which the police's primary purpose is not to obtain evidence for trial but to address a danger to public. Turkish law disregards the emergency circumstances in which the lives, liberty and bodily integrity of individuals can be under threat and that the police may need to interrogate suspects only to counter an imminent threat rather than to obtain evidence. In such

1 The names of the interviewees are on file with the author, and will not be provided in this paper for confidentiality reasons. 
cases, it might be too late to prevent a substantial danger to public by the time warnings are read and counsel provided. The U.S. Supreme Court and ECtHR observed this need and generated an exception that allowed the temporary deprivation of procedural warnings and the right to counsel in cases of an urgent public safety threat. The article suggests the Turkish legal system to establish a similar exception for the purpose of more effective counterterrorism.

Second, the article addresses a common complaint stated by senior Turkish counterterrorism officials in interviews: unethical defense counsel may act to promote a terrorist organization or obstruct the administration of justice. Under Turkish counterterrorism officials' experience, some lawyers take part in the same terrorist organization with a terror suspect, and coerce him to give his statement in a particular way, or facilitate the exchange of information between a terrorist organization and a suspect or between suspects. The article acknowledges that these allegations may stem from personal bias against the lawyers of terror suspects. Nevertheless, it takes these claims seriously and thinks over potential measures the law should take if defense counsel misuse their legal power.

Turkish law prohibits defense counsel from defending a suspect who is accused of establishing an organization to commit crimes, or establishing, directing or membership in an armed organization, or of terror crimes in every stage of criminal proceedings, if there is a prosecution against the counsel for these offenses. A ban can be imposed via a judicial order for a year and can be extended two times for six months. The banning order can be issued only for the crime that is the subject of an accusation ([C.M.K.], 2004, art. 151-3, 4). The existing rule precludes lawyers who are tried for certain crimes from defending suspects/defendants accused of similar crimes. Yet, it does not address the cases when defense counsel acts to obstruct justice or hinder counterterrorism efforts through abusing his communication with his client during police interrogation, without any criminal proceedings underway against him. The current rule does not allow the immediate exclusion of unethical defense counsel from police interrogation, and requires an ongoing prosecution to be formed. However, any attempt to block the administration of justice or to advance terrorist activities should be thwarted right away in police interrogation in order to protect the integrity of an investigation and to prevent the frustration of counterterrorism efforts.

The article suggests that Turkey should enact a law that allows the immediate exclusion of a defense lawyer from police interrogation via a magistrate judge order (Sulh Ceza 
Hakimi emri) when there is reasonable suspicion (under the professional experience of the police and public prosecutor) that the lawyer; 1) participates in the same criminal activity, or is engaged in the same terrorist organization with his client, or 2) abuses his communication with his client to commit crimes or to protect the terrorist organization and its structure, or to jeopardize the security of a prison. Another lawyer should be appointed by a magistrate judge (Sulh Ceza Hakimi) in place of the excluded counsel.

\section{Procedural Rights in Police Interrogation in the U.S. and ECtHR Jurisdictions}

In democratic countries, individuals are granted with certain procedural rights that are designed to ensure fairness and to prevent arbitrary government action in police interrogation. These rights are the right to counsel, the right to silence, and the right to be informed of these procedural rights, including that anything said can and will be used against the individual in court and that a lawyer will be appointed to him if he is indigent (Miranda v. Arizona, 1966; Ibrahim and Others v. the United Kingdom, 2016, paras. 270-273; LaFave, Israel, King \& Kerr, 2015, pp. 784-785). This section explains the U.S. and European understandings of these common rights, and discusses whether developments in the U.S. law affected the European perspective.

According to the U.S. law, the right to counsel, the right to silence, and the right to be notified of defense rights in police interrogation derive from the Fifth Amendment's privilege against self-incrimination. ${ }^{2}$ The Fifth Amendment to the U.S. Constitution states that no one "shall be compelled in any criminal case to be a witness against himself". The landmark case of Miranda v. Arizona held that the privilege was applicable

2 In Escobedo v. Illinois, the U.S. Supreme Court first decided that the right to counsel before the initiation of the formal charging stemmed from the Sixth Amendment right to counsel (Escobedo v. Illinois, 1964). But the Court changed course in Moran v. Burbine and ruled that the Sixth Amendment right to counsel was applicable only after the initiation of adversary proceedings. That is to say, the Sixth Amendment right to counsel is no longer the applicable rule in police interrogation when a suspect is not yet formally charged by a court. Rather, the Fifth Amendment privilege against self-incrimination governs the right to counsel in custodial interrogation (Saltzburg \& Capra, 2014, pp. 853-855). The purpose of the right to counsel in pre-charge detention is "to guarantee full effectuation of the privilege against self-incrimination" (Moran v. Burbine, 1986). 
to the "inherently compelling" in-custody police questioning. ${ }^{3}$ The privilege against self-incrimination is a measure to determine the proper scope of government power over its citizens. The privilege thereby demands respect for dignity and integrity of citizens as well as for their free will (Miranda v. Arizona, 1966, p. 460). The right to counsel and the right to be informed of these rights do not explicitly exist in the U.S. Constitution. They instead were created by the U.S. Supreme Court as necessary safeguards for the operation of the privilege against self-incrimination (Moran $v$. Burbine, 1986, pp. 429-473; Saltzburg \& Capra, 2014, pp. 853-855).

The European Convention on Human Rights (ECHR), somewhat differently, does not explicitly contain the privilege against self-incrimination, the right to silence, or the right to be informed of procedural rights. It only provides the right to counsel in the text of its Article 6-3-c. Yet, although they are not explicitly written in the Convention, the case law of the ECtHR suggests that the privilege against self-incrimination and the right to silence as well as the right to be informed of procedural rights all derive from the right to a fair trial of Article 6.

The ECHR Article 6-3 states that:

Everyone charged with a criminal offence has the following minimum rights:

(a) to be informed promptly, in a language which he understands and in detail, of the nature and cause of the accusation against him;

(b) to have adequate time and facilities for the preparation of his defence;

(c) to defend himself in person or through legal assistance of his own choosing or, if he has not sufficient means to pay for legal assistance, to be given it free when the interests of justice so require;

(d) to examine or have examined witnesses against him and to obtain the attendance

3 Miranda warnings are required in custodial interrogation cases. A person is deemed to be in custody when he is "deprived of his freedom of action in any significant way" (Miranda v. Arizona, 1966, pp. 461, 467, 477). See also Orozco v. Texas and Beckwith v. United States. A custodial interrogation refers to the "questioning initiated by law enforcement officers after a person has been taken into custody or otherwise deprived of his freedom of action in any significant way" (Miranda v. Arizona, 1966, p. 444).

Rhone Island $v$. Innis decision extended the scope of an interrogation from Miranda's express questioning to include the functional equivalent of an express questioning. That is, under Rhone Island $v$. Innis, “"interrogation' under Miranda refers not only to express questioning, but also to any words or actions on the part of the police (other than those normally attendant to arrest and custody) that the police should know are reasonably likely to elicit an incriminating response from the suspect". This determination should be based "primarily upon the perceptions of the suspect, rather than the intent of the police" (Rhode Island $v$. Innis, 1980, pp. 300-301). See also Arizona v. Mauro (1987). 
and examination of witnesses on his behalf under the same conditions as witnesses against him;

(e) to have the free assistance of an interpreter if he cannot understand or speak the language used in court.

According to the ECtHR, a suspect is entitled to these rights at the very beginning of the charging of a criminal offense. Under the Court's most recent case law, "a 'criminal charge' exists from the moment that an individual is officially notified by the competent authority of an allegation that he has committed a criminal offence, or from the point at which his situation has been substantially affected by actions taken by the authorities as a result of a suspicion against him" (Ibrahim and Others v. the United Kingdom, 2016, para. 249; Deweer v. Belgium, 1980, paras. 42-46; Eckle v. Germany, 1982; McFarlane v. Ireland, 2010). The right to a fair trial thus is effective not only in trial but also in pre-trial proceedings such as during the police interrogation of a charged suspect.

The privilege against self-incrimination, the right to silence, and the right to be informed of the right to counsel and silence are regarded as the byproducts of as well as the means of effectively fulfilling the right to a fair trial (Salduz v. Turkey, 2008, para. 53). In more detail, the ECtHR interpreted the right not to incriminate oneself and the right to silence as internationally recognized standards that "lie at the heart of a fair procedure under Article 6" (Saunders v. the United Kingdom, 1996, para. 68). In Saunders v. the United Kingdom, the Court determined that the right to silence and the right not to incriminate oneself "lies, inter alia, in the protection of the accused against improper compulsion by the authorities thereby contributing to the avoidance of miscarriages of justice and to the fulfilment of the aims of Article 6 (art. 6)." In terms of the right to be notified of procedural rights, the Court ruled that in order for the right to silence and the right to a lawyer be practical and effective rather than theoretical and illusory, a suspect must be made aware of his rights (Dvorski v. Croatia, 2016, para. 82; Salduz v. Turkey, 2008, para. 51). Further, the right to be notified of procedural rights was inherent in the existence of the privilege against self-incrimination, the right to silence and the right to counsel (Ibrahim and Others v. the United Kingdom, 2016, para. 272).

Since Europe and the U.S. accord similar procedural rights to suspects in police interrogation, one might wonder whether the American Miranda rule has been exported to the ECtHR jurisprudence. There is no clear-cut answer to this question. This is because the Miranda case is not utilized as the foundational basis for ECtHR's rulings 
(Weisselberg, 2017, p. 1285). Yet, when the ECtHR's relevant judgments are compared with that of the U.S. Supreme Court, there is evidence that European judges have been influenced by the U.S. law. ${ }^{4}$ That is not to say that ECtHR judges reached the same conclusion as the U.S. Supreme Court in every single case. Their opinions sometimes differ in the same issues arising from these procedural rights. ${ }^{5}$ But the European Court does refer to American law as a relevant comparison. In Ibrahim and Others v. the United Kingdom, for example, the ECtHR compared the European approach with other countries such as the U.S. and Canada. Ibrahim is the only case the Court explicitly touched upon the Miranda decision. Further, it can also be assumed that ECtHR judges are familiar with the U.S. law especially because of their distinguished legal background with knowledge of foreign legal developments, including the U.S. (Weisselberg, 2017, pp. 1284-1285). All these factors demonstrate that although defense rights in a police interrogation are not exported from the U.S. to Europe, there is evidence that U.S. Supreme Court judgments influenced the European approach at a certain level.

\section{Turkish Law, Its Gaps, and Suggestions Based on Comparative Law and Interviews}

Turkish law requires mandatory counsel in cases when the minimum statutory punishment is at least five years of imprisonment. Since terror crimes (except terrorist propaganda) require at least five years of incarceration, the presence of counsel during interrogation and trial stages is mandatory in most of the terror cases. The law also requires that, regardless of the minimum incarceration period, a statement obtained in police interrogation without the presence of counsel may not be used as primary evidence in court unless the defendant confirms. This rule creates an incentive for the police to provide counsel no matter how serious a crime is just to make sure that a statement be considered as evidence at trial. Thus, we may conclude that there is an implied mandatory counsel for all criminal cases ([C.M.K.], 2004, art. 148-4, 150-3; Yenisey \& Nuhoğlu, 2015, p. 201; Centel \& Zafer, 2013, p. 173; Soyaslan, 2016, pp. 184-185).

4 For example, the ECtHR in Pishchalnikov was influenced by the U.S. Supreme Court's Edwards decision (Pishchalnikov v. Russia, 2009; Edwards v. Arizona, 1981).

5 Such as in the cases of ECtHR's Dvorski and the U.S. Supreme Court's Burbine. In the former case, the ECtHR ruled that the police had to inform the suspect of the fact that his family hired another lawyer for him, and the lack of this knowledge deprived the suspect of informed choice of a lawyer and defense rights. In the latter case, however, the U.S. Supreme Court ruled that the police did not have the obligation to inform the applicant of the presence of a lawyer in the stationhouse (Dvorski v. Croatia, 2016; Moran v. Burbine, 1986, pp. 429-430). For more information, see Weisselberg, 2017, p. 1262. 
A terror suspect thus cannot be deprived of his mandatory right to counsel during investigation and trial stages, with one exception: the right to counsel can be restricted for 24 hours by a judicial order issued upon request of a public prosecutor. Yet, even in that case, the police cannot interrogate the suspect ([C.M.K.], 2004, art. 154-2). In most of the terror crimes, any police interrogation without the presence of counsel is strictly prohibited in Turkish law. The number of counsels is limited to three in all cases during police interrogation, and in terror cases during trial ([C.M.K.], 2004, art. 149-2; Yenisey, 2015, p. 581; Yenisey \& Nuhoğlu, 2015, p. 198; Centel \& Zafer, 2013, p. 177).

Under Turkish law, the police are required to warn suspects of the right to counsel, the right to silence, the right to inform relatives about detention, and of the right to demonstrate the evidence in favor of him to clear any suspicion against him. These rights are required to be reminded at the beginning of the police's and prosecutor's interrogation as well as at trial stages. Both the U.S. Supreme Court and the ECtHR have developed a public safety exception that allows unwarned custodial interrogation when necessary to address an urgent public safety interest (New Yorkv. Quarles, 1984; Salduz v. Turkey, 2008, para. 55; Ibrahim and Others v. the United Kingdom, 2016, para. 259). But no such exception exists in Turkey. Thus, unwarned statements, even in the cases of imminent danger, are inadmissible in Turkish courts (T.C. Anayasas1 [AY], 1982, art. 38-6; [C.M.K.], 2004, art. 147-1-c, d, e, f, 289-1-i; Öztürk et al, 2015, p. 398; Centel \& Zafer, 2013, pp. 215-217; Soyaslan, 2016, pp. 345-349; Yenisey, 2015, pp. 489-493; Yenisey \& Nuhoğlu, 2015, pp. 619-623).

This paper proposes two types of amendments to Turkish law: 1) A public safety exception to the right to counsel and the right to be informed of procedural rights, and 2) The exclusion of defense lawyers in certain limited circumstances. While the former suggestion fills a legal hole in the Turkish system when compared to ECtHR and U.S. jurisdictions, the latter is developed as a legal solution to a problem stated by the interviewed counterterrorism officials. First, the public safety exception should be adopted that would allow unwarned custodial interrogation, outside the presence of counsel, in cases when there is an urgent need to protect the life and bodily integrity of third persons. That is, in exceptional cases when there is "an urgent need to avert serious adverse consequences for the life, liberty or physical integrity of a person", there is a sufficient and compelling reason to dispense with warnings and counsel (Ibrahim and Others v. the United Kingdom, 2016, paras. 210, 259, 300). 
Second, the exclusion of defense lawyers is proposed to counter the issue of unscrupulous counsel, whose aim is to obstruct the administration of justice by either coercing terrorism suspects to remain silent or facilitating an exchange of information between a terrorist organization and a terror suspect, or between suspects. The parts below examine the two proposals of the public safety exception and the exclusion of defense lawyers, and provide some relevant information on foreign laws when necessary.

\subsection{A Public Safety Exception to the Right to Counsel and the Right to Be Informed of Procedural Rights}

This part initially explains the U.S. and European laws with regard to procedural rights in emergency conditions, which allow the temporary restrictions on the right to counsel and the right to be informed of procedural rights in these situations. Emergency conditions refer to cases when there is an urgent public safety need to protect the life, liberty and physical integrity of the public. Then, it describes the relevant Turkish law and makes suggestions to improve the current law.

\subsubsection{The United States}

The U.S. Supreme Court established a public safety exception to Miranda rights in New York v. Quarles. Under the public safety exception, Miranda rights need not be provided to a suspect when information must be obtained to protect against an imminent threat to the safety of others. The evidence obtained therefrom thus would not be regarded as illegally obtained and would be admissible.

In Quarles, a police officer did not caution an arrestee when he detained him and immediately asked the whereabouts of a gun after seeing the empty holster on the suspect. The suspect pointed him to the gun. The U.S. Supreme Court determined that un-Mirandized statements obtained to prevent a danger to public were admissible at trial. The Court ruled that the police "were confronted with immediate necessity of ascertaining the whereabouts of a gun which they had every reason to believe the suspect had just removed from his empty holster and discarded in the supermarket". More strikingly, the Court emphasized that the primary reason for added Miranda protections in the expense of fewer convictions was to effectuate the Fifth Amendment privilege against self-incrimination. The Miranda Court bore the burden of fewer convictions to protect the privilege against self-incrimination. In this case, however, the cost would be more than a simple failure to obtain evidence useful to build a case against Quarles for his conviction. The cost would be substantial danger to the public, 
thus changing the balance between individual and public interests that the Miranda Court had struck (New York v. Quarles, 1984, pp. 652, 657).

\subsubsection{The European Court of Human Rights}

The ECtHR permits temporary restrictions on the exercise of the right to counsel and the right to be informed of the right to silence in cases when there are compelling reasons such as a threat against public safety (Ibrahim and Others $v$. the United Kingdom, 2016, para. 259; Salduz v. Turkey, 2008, para. 55; Borg v. Malta, 2016). Compelling reasons thus would justify any failure to inform the suspect of his rights during interrogation. Similar to the U.S. Supreme Court's Quarles decision establishing a public safety exception to Miranda warnings, ECtHR also established a "compelling reasons" exception to the exercise of the right to counsel via the Salduz and Ibrahim cases, and the right to be informed of the right to silence via the Ibrahim case. Turkey also should establish an exception to Miranda rights in exceptional cases of urgent public interest, when it would be lawful for the police to question a person without warnings and without a lawyer present.

In Salduz v. Turkey, a minor was taken into custody for taking part in an illegal demonstration that praise the leader of the PKK and suspending an illegal placard from a bridge. He was later found guilty of aiding and abetting the PKK. The minor was not provided with a lawyer during police interrogation. The Court held that there had been a violation of Article $6 \S 3$ (c) (the right to legal assistance of one's own choosing) together with Article $6 \S 1$ (the right to a fair hearing) of the Convention, given the absence of a lawyer for the minor's defense during police custody (Salduz v. Turkey, paras. 57-63, 77). The Court further stated that the right to access to a lawyer could be denied only when there were "compelling reasons" for a restriction. Such denial nevertheless could not unduly prejudice the right to a fair trial under Article 6. The important part of the decision is as follows:

In order for the right to a fair trial to remain sufficiently "practical and effective", ... access to a lawyer should be provided as from the first interrogation of a suspect by the police, unless it is demonstrated in the light of the particular circumstances of each case that there are compelling reasons to restrict this right. Even where compelling reasons may exceptionally justify denial of access to a lawyer, such restriction - whatever its justification - must not unduly prejudice the rights of the accused under Article 6. The rights of the defense will in principle be irretrievably prejudiced 
when incriminating statements made during police interrogation without access to a lawyer are used for a conviction (Salduz v. Turkey, 2008, para. 55).

Ibrahim and Others $v$. the United Kingdom is a leading and relatively new decision holding that in cases of danger to public safety or if urgencies of the situation require, it is lawful to temporarily restrict the exercise of the right to counsel and the right to be informed of the right to silence. Compelling reasons exist when there is "an urgent need to avert serious adverse consequences for life, liberty or physical integrity" of the public (Ibrahim and Others v. the United Kingdom, 2016, paras. 276, 298).

In Ibrahim, the Court specifically evaluated whether safety interviews with a terror suspect can be conducted without counsel present in the interrogation room for the purposes of obtaining information that would preserve and secure public safety. The purpose of a safety interview is to determine the whereabouts of other known accomplices, identities and unknown accomplices involved in the commission, preparation and instigation of acts of terrorism, and the presence of other explosive devices or materials likely to cause danger. Safety interviews are conducted in cases when delaying an interview would involve "immediate risk of harm to persons or serious loss of, or damage to, property", or "the alerting of other persons suspected of committing a terrorist offence but not yet arrested" (Ibrahim and Others $v$. the United Kingdom, 2016, paras. 28, 40, 43).

The Ibrahim case involved four applicants who were suspected of detonating four bombs which failed to explode on the London transportation system on 21 July 2005. Three of them were immediate suspects of a terror investigation involving a detonation of a bomb which failed to explode. The fourth applicant was initially a witness but subsequently became a suspect for sheltering one of the main perpetrators. The first three applicants received warnings and were then interviewed by the police (safety interviews) without counsel present. The fourth applicant was questioned first as a witness, and then as a suspect after he made self-incriminating statements. Yet, he was not reminded of his rights and was not provided with counsel when he began incriminating himself during questioning as a witness.

The ECtHR discussed whether compelling reasons would justify the lack of counsel in the first three applicants' case, and the lack of counsel and of any notification of his procedural rights (regarding privilege against self-incrimination) in the fourth applicant's case (Ibrahim and Others v. the United Kingdom, 2016, paras. 271, 295, 299, 303). 
Regarding the first three applicants' questioning, the Court ruled that there was "an urgent need to avert serious adverse consequences for life, liberty or physical integrity" of the public. Since a similar type of an attack in the transportation facilities of London killed more than fifty people two weeks earlier, the police had sufficient reason to think that London was subjected to a wave of terror attacks, and that there were other accomplices to the current attempt or that other explosive devices were planted somewhere else. Hence, the Court ruled that compelling reasons to protect the public from further suicide attacks justified the temporary deprivation of the right to counsel. Regarding the fourth applicant, who was initially questioned as a witness but then as a suspect, the Court was not satisfied under the circumstances of the case that there were compelling reasons to deprive him his right to counsel as well as procedural warnings (Ibrahim and Others $v$. the United Kingdom, 2016, paras. 14-57, 276, 300). ${ }^{6}$ In sum, the gist of the Ibrahim case is the determination that the temporary restriction of the right to counsel and the right to be notified of procedural rights would be lawful if compelling, safety-based reasons exist (Barkhuysen et al., 2018).

\subsubsection{A Suggestion to the Turkish System}

The examination of the U.S. and ECtHR jurisdictions revealed that a public safety exception to the right to counsel and the right to be informed of procedural rights was lacking in the Turkish system. Turkish law may also recognize a public safety exception via a judgment by the Constitutional Court or a statutory amendment to the Criminal Procedure Code.

First, Turkey is a party to the European Convention, and ECtHR judgments are binding for Turkish authorities. ${ }^{7}$ It may be that when a national law provides a higher protection

6 It is worth noting that the Court cited the U.S. Supreme Court's Miranda and Quarles judgments to support its compelling reasons exception (Ibrahim and Others $v$. the United Kingdom, 2016, paras. 229, 230, 259).

7 Turkey had been one of the founding members of the Council of Europe that was established in 1948 after World War II (MFA, 2011; CoE, 2020b). It ratified many human rights conventions and protocols signed under the Council of Europe, one of which is the European Convention on Human Rights. The European Convention on Human Rights was signed in Rome in 1950, and entered into force in 1953 (CoE, 2019a). It was ratified by the Turkish Parliament and entered into force in 1954 (CoE, 2020a). The Council established the European Court of Human Rights to ensure the proper application of the European Convention and its additional protocols (CoE, 2019a). Turkey recognized the right of individual petition to the European Court of Human Rights in 1987, and accepted the Court's compulsory jurisdiction in 1990 (PACE, 1992; Ekinci \& Sağlam, 2015, p. 2). For more information regarding the Council of Europe, the ECHR, and its Court, see (CoE, 2019b; MFA, 2011).

The European Court of Human Rights judgments are binding for Turkish courts under Article 46 of the Convention and the Turkish Constitution Article 90. First, Article 46 states that ECtHR judgments have binding force over member states, one of which is Turkey. Second, Article 90 of the Turkish Constitution states that international agreements on human rights norms would prevail over statutes if any contradiction exists. 
than ECHR, the lower standards of the ECtHR's case law is not binding for a contracting state and cannot be applied to the prejudice of defendants. Nevertheless, Turkish Constitutional Court may well recognize the compelling reasons exception of Salduz and Ibrahim and incorporate it into the Turkish system through a judgment if a similar issue comes before the Court. ${ }^{8}$

Second, an amendment to the Turkish Criminal Procedure Code may recognize unMirandized statements and statements obtained without the presence of counsel as admissible if obtained under emergency conditions. This may raise constitutionality issues under Article 38-6 of the Constitution, which prohibits the use of illegally obtained findings as evidence. If the legislator establishes a public safety exception to procedural rights, obtaining statements in urgent circumstances without procedural warnings or counsel present would be lawful. These statements and other derivative evidence would not be considered as illegally obtained. Therefore, the public safety exception would be constitutional.

The balancing test between the privilege against self-incrimination and the heightened state interest in protecting the lives, liberty and physical integrity of third persons weighs in favor of the latter social interest. This outcome is the reason to establish a public safety exception to the privilege against self-incrimination which demonstrates itself through the right to counsel, the right to silence, and the right to be notified of these rights. The right to counsel and the right to be notified of procedural rights thus should be limited in exceptional emergency conditions when the protection of the life, liberty and physical integrity of innocents justifies the practice.

8 For example, Quarles decision was utilized as a supporting argument in the dissenting opinion of a Turkish High Court of Appeals (Yargitay) judgment. The Turkish High Court of Appeals (Yargitay) discussed whether the lack of Miranda warnings during trial proceedings, as required by [C.M.K.] art. 147 (then art. 135), constituted a reason for vacate and remand decision even when a defendant was acquitted by a trial court. According to the majority opinion, procedural rules were of primary importance and incompliance with them would result in a vacate and remand decision, even though the defendant was acquitted. The dissenting opinion, however, argued that if the violation of a procedural rule did not affect the judicial outcome, the trial court decision must not be vacated and remanded. The dissent defended a balancing test that weighs opposing interests and utilized the U.S. Supreme Court's Quarles decision as a supporting argument (C.G.K. 24.10.1995 E.1995/6-238 K. 1995/305).

The judgment shows that Turkish High Courts may resort to the high court decisions of other countries to shape and improve Turkish law, regardless of whether they are binding. That is, the Constitutional Court may justifiably make use of ECtHR judgments ---at least as supplementary sources, in order to generate a compelling reasons (or public safety) exception to procedural rights. 


\subsection{The Exclusion of Defense Counsel}

The presence of counsel is necessary during police interrogation for three reasons: First, it clears the doubts of coercion or inhuman treatment by the police. Second, the police make sure with a lawyer's presence that warnings are given about procedural rights. Third, it ensures the voluntariness of a statement. Having said that, an interviewed security official, a public prosecutor and a judge claim that it is possible for defense counsel to have a relationship with a terrorist organization that goes beyond client defense. According to these interviewees, there have been occasions when defense lawyers act to obstruct justice and hinder effective counterterrorism efforts. Examples include coercing their clients to remain silent, or facilitating the exchange of information between a terrorist organization and a suspect or between suspects. For instance, in PKK cases, young militants generally admit to talk to the police regarding terrorist activities. Yet, the lawyer sent by the PKK to defend a young militant threatens him with his or his family members' lives and coerces him to not to give any statement to security officials. Moreover, in some cases, a lawyer is associated with a terrorist organization and defends many terror suspects at the same time. This creates the risk that a suspect's statement will be transferred to other suspects to ensure consistent statements, which might lead to fabricated but uniform stories obstructing justice (See also HRW, 2019, p. 32). These attempts not only impede the administration of justice but also preserve and promote a terrorist organization.

Defense lawyers, on the other hand, claim that they face intense pressure from the police, public prosecutors and courts. According to the Human Rights Watch (HRW), many lawyers are charged with membership in a terrorist organization or terrorist propaganda without compelling evidence, just because they defend terror suspects or expressed views in support of a terrorist organization in social media or phone conversations. Moreover, the police and public prosecutors retaliate against lawyers for defending suspects who sue police officers, for arguing with them, or documenting human rights violations by the police (HRW, 2019, pp. 22-49). According to a prolawyer report, since 2016's coup attempt, more than 1500 lawyers have been prosecuted, 605 lawyers were arrested and 345 were convicted of membership in a terrorist organization or terrorist propaganda (The Arrested Lawyers Initiative \& CNF, pp. 7-8).

Regardless of whether these allegations and numbers are completely accurate, it is evident that the trustworthiness of defense counsel is under question. The interviews with counterterrorism officials and the conviction rate suggest that some lawyers may 
actually be engaged in the activity of a terrorist organization, even though there may be arbitrary investigations and prosecutions in some cases. Some lawyers may be dedicated to the ideology of a terrorist organization and may provide legal support for its illegal activities, while others may defend a terror suspect for the sake of the right to counsel and professional responsibility. In any case, the state must take necessary precautions to prevent any attempt to obstruct the administration of justice or counterterrorism efforts.

The solution to counter these problems in the Turkish system is not to deprive a terror suspect from legal advice. It is to ensure that a lawyer is not engaged in the criminal activity of an accused, does not threaten a suspect, and does not facilitate information exchange. For this reason, lawyers who are suspected of; 1) engaging in the same criminal activity with an accused, or 2) coercing a suspect, or 3) facilitating information exchange between an organization and a suspect or between suspects, or 4) aiming to obstruct justice or hinder counterterrorism efforts in other ways, should be excluded from the proceedings in the Turkish system. Turkish law needs an enactment allowing the exclusion of defense lawyers in these four circumstances. The exclusion should be made via a magistrate judge order upon a showing of reasonable suspicion.

This part first analyzes German law which authorizes the exclusion of defense counsel in cases of attempts to obstruct justice. Then, it focuses on a possible amendment to Turkish law that would follow the German model, and scrutinizes whether the proposal passes the constitutionality muster and satisfies the ECtHR standards.

\subsubsection{The Exclusion of Defense Counsel under German Law}

The German Criminal Procedure Code Article 138a permits the exclusion of defense counsel from proceedings in cases when counsel aims to obstruct justice. The article states that:

“(1) Defense counsel shall be excluded from participation in proceedings if he is strongly suspected, or suspected to a degree justifying the opening of the main proceedings,

1. of being involved in the offence which constitutes the subject of investigation,

2. of abusing communication with an accused who is not at liberty for the purpose of committing criminal offences or substantially endangering the security of a penal institution, or 
3. of having committed an offence which in the event of the conviction of the accused would constitute accessoryship after the fact, obstruction of justice or handling stolen goods.

(2) Defense counsel shall also be excluded from participation in proceedings the subject of which is a criminal offence pursuant to section 129a, also in conjunction with section $129 \mathrm{~b}$ subsection (1) of the Criminal Code, if certain facts substantiate the suspicion that he has committed or is committing one of the acts designated in subsection (1), numbers 1 and 2." (Strafprozeßordnung [StPO], 1987, § 138a-1, 2)

The exclusion of defense counsel is allowed in every stage of proceedings both in regular crimes (138a-1) and terror crimes (138a-2, 129a that refers to terror offenses under German Criminal Code). While strong suspicion or suspicion "to a degree justifying the opening of the main proceedings" is required for regular crimes, a simple level of suspicion is enough for the exclusion of lawyers in terror cases. In terror cases, the Code only requires that certain facts support the suspicion that a lawyer; 1) is involved in the criminal activity of the accused, or 2) abuses his communication with the accused in order to commit criminal offences or endanger the security of a penal institution ([StPO], 1987, § 138a-1, 2; Oehmichen, 2009, pp. 243, 252). ${ }^{9}$

\subsubsection{An Amendment to Turkish Law}

According to the Turkish Criminal Procedure Code Article 151-3\&4, defense counsel can be prohibited via a judicial order from defending a terror suspect, defendant or a convict, if there is an ongoing prosecution against him for establishing an organization to commit crimes, establishing, directing or membership in an armed organization, or for terror crimes (Centel \& Zafer, 2013, p. 191; Soyaslan, 2016, pp. 188-189; [C.M.K.],

9 Germany adopted two more new laws as a reaction to; 1) the large number of defense lawyers who seemed to obstruct the trial, and 2) the fact that the defense of several accused persons by the same lawyer seemed to facilitate information exchange between those accused. According to these enactments, the defense counsel chosen by a defendant were limited to three, and lawyers could no longer defend more than one person accused of the same deed ([StPO], $1987 \S 137-1$ ). The German Federal Constitutional Court later regarded this limitation as constitutional, finding that it did not conflict with the right to an effective defense or the right to a fair trial. The Court reiterated that the purpose of the limitation was "to impede the accused from delaying the proceedings by using several defense lawyers, so that it served the objective to ensure a due procedure and to maintain the functioning of the criminal justice system as required by the rule of law". The right to a fair trial can be exercised with up to three defense counsels, even in "extraordinary heavy and protracted proceedings" (Oehmichen, 2009, p. 244).

Turkey also limited the number of lawyers to three in the adjudication of terror crimes in 2016 ([C.M.K.], 2004, art. 149-2).

In addition, the Turkish Advocacy Code obliges lawyers to refrain from defending persons with conflicting interests in the same case (Avukatlik Kanunu [A.K.], 1969, art. 38-1-b). 
2004, art. 151-3; Türk Ceza Kanunu [T.C.K.], 2004, art. 220, 314). The judicial order can be issued upon request of a public prosecutor, and will only be issued for the crime that is the subject of the accusation. The initial ban is for a year, but it can be extended for six months, two times, depending on the circumstances of the offense. The ban may be contested by the banned lawyer. It automatically gets lifted, if; 1) the lawyer's objection is found reasonable by the court, or 2) the lawyer is not convicted at the trial stage ([C.M.K.], 2004, art. 151-4).

Turkish law allows the exclusion of a defense lawyer only in a case when the lawyer himself is under prosecution for certain crimes. The current statutory rule does not focus on the fact that a defense lawyer may be furthering the criminal activity of the accused without an ongoing prosecution of the lawyer, or the fact that a defense lawyer might be facilitating the exchange of information between the accused and his terrorist organization or between suspects. The rationale of the current statute is to prevent lawyers who are prosecuted for particular serious crimes from defending suspects accused of similar offenses. A prosecution is thus the condition of such an exclusion. However, the limitation fails to include the instant exclusion of a lawyer from police interrogation when there is a reasonable basis that he is engaged in the activity of a terrorist organization or misused his relationship with his client.

Turkish law needs an amendment similar to German law, in order to assure that any attempts to block the administration of justice or to further terrorism, at the hands of defense counsel, are thwarted. A defense lawyer who aims to obstruct justice through abusing his communication with a terror suspect or to secretly assist a terrorist organization under the name of defending his client, should be immediately prevented from frustrating trial fairness and counterterrorism efforts. The state should not wait for a prosecution to be initiated, as the police would need to act swiftly to counter any efforts that dishonor proper investigation and effective counterterrorism. When a lawyer is excluded, another lawyer should be appointed in his place, and the police interrogation must cease until the newly appointed lawyer arrives at the interrogation room. Otherwise, evidence obtained through an interrogation made in the absence of the new lawyer would be inadmissible at trial.

The magistrate judge on duty at the time of police interrogation can be authorized to issue the orders of exclusion. This proceeding must be conducted ex parte as it may involve confidential intelligence information indicating the abuse of relationship as well as membership. Access to intelligence information by a lawyer may disclose 
intelligence gathering activities as well as intelligence sources. The exclusion order should be automatically revoked unless a prosecution has been initiated for the lawyer within one year after exclusion.

The suitable level of cause in enactment should be determined under a balancing test. Under the balancing test, the appropriate level of cause is to be set by comparing conflicting individual rights and state interests. The individual interest in this particular case is the right to counsel of one's choice. While choice is important, the right to a fair trial would not be substantially infringed by the appointment of another lawyer, as the suspect would be represented by and be given the assistance of a lawyer during interrogation. So long as the appointed lawyer is not prejudiced against the suspect and protects the suspect's interests, there would not be a significant individual rights infringement --- that is to say, the right to counsel of choice must give way to the state interest in protecting against terrorism. Since there is a lesser intrusion on individual rights, as opposed to the considerable state interest in this case, the use of a simple level of suspicion should suffice. Reasonable suspicion (in the U.S. sense) that derives from the professional experience of the police and prosecutors should be enough for excluding lawyers from interrogation.

Further, preventive counterterrorism measures like the proposed law (i.e. preventive electronic surveillance) usually require reasonable suspicion as their purpose is to eliminate any threats to national security, namely to prevent future terror attacks (Polis Vazife ve Salahiyet Kanunu [P.V.S.K.], 1934, Supp. art. 7-2; Jandarma Teşkilat, Görev ve Yetkileri Kanunu [J.T.K.], 1983, Supp. art. 5-1; Devlet İstihbarat Hizmetleri ve Milli İstihbarat Teşkilatı Kanunu [M.I.T.K.], 1983, art. 6-2). Thus, reasonable suspicion may be a suitable standard also for excluding lawyers for preventive purposes.

The concrete evidence necessary for the establishment of the probable cause standard could be a hard burden on authorities. This is because it might be difficult to obtain concrete evidence right away at the very instance of interrogation. Thus, the article recommends that when the police and public prosecutor suspect under their experience and knowledge that the lawyer aims to obstruct justice and hinder counterterrorism efforts, he should be replaced with another lawyer via a magistrate judge order. ${ }^{10}$ More specifically, a prospective enactment may rule that a defense lawyer might be excluded from police interrogation if there is a basic level of suspicion (reasonable suspicion)

10 The City Bar Association must provide a list of lawyers available on a certain date and time, and the magistrate should appoint a lawyer from the list. 
under the professional experience of the police and public prosecutor that the lawyer;

1. participates in the same criminal activity or is engaged with the terrorist organization of an accused, or

2. abuses his communication with his client to commit crimes or to protect the terrorist organization and its structure, or to jeopardize the security of a prison.

This amendment potentially has many advantages: First, it would contribute to the realization of justice by preventing the fabrication of false but consistent statements by terror suspects. Second, it would prevent a terrorist organization's lawyer from protecting the leader cadre as well as the structure of the organization in the guise of defending a suspect. Third, it would help authorities to better spot the hierarchy, organizational structure and future plans of an organization thanks to more effective police interrogation. And fourth, it might also hamper any efforts to kidnap a terror suspect from a prison facility like a stationhouse, by limiting the physical interaction between an organization's lawyer and a terror suspect.

\subsubsection{Constitutionality Analysis}

The constitutionality of the proposed law may be challenged before the Constitutional Court under Article 36-1 (the right to a fair trial) of the Turkish Constitution. In that case, the Court will make an analysis considering the proportionality principle deriving from Article 2 (the state of law) and Article 13 (Restriction of fundamental rights and freedoms). The proportionality involves four elements "proper purpose (legitimate aim)", "suitability (rational connection)", "necessity" and "proportionality in the narrow sense (balancing test)" (AYM 14.6.2017 E: 2017/24 K: 2017/112; AYM 24.7.2019 E: 2018/73 K: 2019/65; AYM 27.12.2018 E: 2018/153 K: 2018/119; AYM 07.09.2016 E: 2016/124 K: 2016/155; AYM 01.11.2017 E: 2017/142 K: 2017/150; Tanör \& Yüzbaş1oğlu, 2001, pp. 151-152; Gözler, 2000, pp. 258-260; Metin, 2002, pp. 209-245).

First, the proper purpose element requires an overriding interest to justify any human rights intrusion. These interests may be the protection of others' rights, or public interests such as national security, public order, public health and the protection of minors. The exclusion of defense lawyers aims to protect the integrity and proper functioning of the criminal justice system, prevent the interruption of counterterrorism measures, and ensure an effective defense and a fair trial for the suspect. Thus, it would serve the purposes of national security, public order and protection of human rights. 
Second, suitability demands that there is a rational connection between means chosen and the proper purpose. The limiting law should realistically be able to realize the desired result. The exclusion of an unethical lawyer from police interrogation and the appointment of another lawyer in his place would ensure that the suspect gives a statement under his free will, his defense rights are not disregarded, and any attempts to interfere with counterterrorism are thwarted (Barak, 2012, pp. 245, 255-256, 268269, 303, 305; Klatt \& Meister, 2012, p. 8; Schlink, 2012, pp. 722-725).

Third, the necessity requires that the least restrictive measure is used to realize the desired result. If there are various suitable alternatives that may equally advance the proper purpose, the less restrictive option must be preferred (Barak, 2012, pp. 317, 323; Klatt \& Meister, 2012, p. 8). Disciplinary sanctions or criminal prosecutions against unethical lawyers might be considered as potential alternatives. Yet, these measures involve more limitations than the exclusion, as they would have long term effects on the legal career of a lawyer. Further, these measures would hardly bring about the desired effect, which is the immediate halt to any attempts to obstruct justice and disrupt the fight against terrorism. The replacement of unethical lawyers with another lawyer thereby appears to be the most suitable and the least restrictive alternative.

Fourth, the proportionality in the narrow sense (the balancing test) balances the benefits gained by the restricting measure and the harm directed at an individual right. The balancing test weighs the social importance of a restricted individual right against the social importance of the legitimate aim advanced by the intrusion (Barak, 2012, pp. 340, 349; Klatt \& Meister, 2012, p. 8). On the one hand, the exclusion of unethical defense counsel infringes on the right to counsel of one's choice and the right to a fair trial ([C.M.K.], 2004, art. 149-150; [AY], 1982, art. 36). The right to counsel has paramount importance in assuring the voluntariness of a statement during custodial interrogation and contributing to the fairness of a trial. Turkey has a long history of police coercion during interrogation, and the right to counsel operates as an indispensable safeguard against arbitrariness (HRW, 2000). Hence, Turkish law cannot dispense with the very safeguard of the right to counsel. In this particular case, the right to counsel is not completely eliminated by the proposed measure since an interrogation will be ceased immediately after the exclusion and the suspect will be able to consult with another lawyer during all criminal proceedings. Thus, the measure does not do away with the right to counsel but instead promotes the effective exercise of the right to counsel and contributes to the realization of the right to a fair trial. 
On the other hand, the proposed measure protects the integrity of the criminal justice system by ensuring that suspects are not coerced by unethical lawyers during police interrogation and that the substituting lawyer provides an effective defense. It also prevents information exchange between a suspect and a terrorist organization or suspects, contributing to counterterrorism efforts. Since there is a limited intrusion on the right to counsel as opposed to the considerable public interest in the proper administration of justice and national security, there is a fair balance between the benefits and harms of the measure.

The proposed law reasonably satisfies all components of the proportionality standard, namely the proper purpose, suitability, necessity, and the balancing test. Therefore, the intrusion on the right to a fair trial (Article 36) would pass the constitutionality muster under Articles 2 and 13, if the Constitutional Court made a similar analysis.

\subsubsection{The Proposal's Compatibility with Relevant ECtHR Judgments}

The European Convention on Human Rights requires in Article 6-The Right to a Fair Trial/3-c that everyone charged with a criminal offense has the right "to defend himself in person or through legal assistance of his own choosing". The relevant issue in this proposal is whether the exclusion of selected counsel and the appointment of new counsel by a magistrate judge violates Article 6 .

The ECtHR has ruled in many cases that the right of an accused to be defended by counsel of "his own choosing" is not absolute. The defendant's wishes can be overridden "when there are relevant and sufficient grounds for holding that this is necessary in the interests of justice" (Croissant v. Germany, 1992, para. 29; Martin v. Estonia, 2013, para. 90; Meftah and others v. France, 2002, para 45; Dvorski v. Croatia, 2016, para. 79,82 ). Therefore, the right to counsel of one's own choosing can be restricted if the interests of justice demand that the accused is defended by court-appointed counsel.

With regard to the current proposal, the issue before us is whether any efforts of obstruction of justice by selected counsel would amount to "sufficient grounds" to conclude that it is "necessary in the interests of justice" to disregard the right to counsel of one's choice. In order to address this issue, the precedents of the Court should be assessed carefully. The Court ruled that there were sufficient grounds to disregard an accused's wishes in cases when; 
a) a lawyer did not have the qualifications of a licensed advocate, ruling that such qualifications were required to ensure "the efficient defense of a person" and "the smooth operation of the justice system" (Zagorodniy v. Ukraine, 2011, para. 53; Meftah and others v. France, 2002, para. 45),

b) the defendant requested to be defended by his mother and sister, and the Court ruled that they were not qualified as professional advocates and would not have been able to "ensure efficient defense in compliance with the procedure" (Mayzit v. Russia, 2005, para. 68),

c) the defendant requested his uncle to be his representative even though he was already represented by an advocate of his choosing (Popov v. Russia, 2006, para. 174),

d) there was a conflict of interest between suspects/defendants represented by the same counsel (Croissant v. Germany, 1992, para 30; Martin v. Estonia, 2013, para. 90),

e) the adequate representation of a suspect required the appointment of different counsel, considering the length, size and the complexity of a case, and the possession of certain qualifications needed for a case (Croissant v. Germany, 1992, para. 28).

In sum, the Court finds that there are sufficient grounds in the interests of justice to appoint a lawyer against a suspect's (or defendant's) wish in cases when; 1) a suspect's interests in trial fairness and an effective defense required so, or 2) the representation by a selected lawyer would contradict with professional responsibility and ethical rules. ${ }^{11}$

My proposal requires court-appointed counsel in cases when there is reasonable suspicion that a lawyer representing a terror suspect is associated with the same terrorist organization, or facilitates information exchange between the suspect and terrorist organization or between terror suspects. The proposal serves many functions. First, it ensures that a suspect is defended by a lawyer who puts his client's interests first rather than the interests of a terrorist organization or another suspect. Second, it furthers counterterrorism and security efforts of the state by hampering information exchange

11 The U.S. law recognizes the right to counsel of one's own choice as a constitutional right under the Sixth Amendment. Similar to the ECtHR, the U.S. Supreme Court generated some exceptions to the constitutional right to counsel. A person cannot be represented by the counsel of his choice in cases when a) there is a conflict of interest between two defendants, b) an advocate is not the member of the Bar, c) he cannot afford the representation by an attorney, d) the attorney declines to represent the client for other reasons (Wheat v. United States, 1988, pp. 159-160). The right to counsel of one's choice is thus not absolute, and is subject to a balancing test between competing interests.

It is likely that the U.S. Supreme Court deems it constitutional to exclude the defense counsel who are engaged in terrorism, if a similar counterterrorism need as in Turkey emerges in the U.S. Therefore, counterterrorism needs would override the right to counsel of one's choice under the U.S. balancing test as well. 
between arrested members and the leader cadre of a terrorist organization. Third, it assures that a lawyer who violates advocacy principles does not take part in criminal proceedings, and thereby protects the integrity of a criminal justice system. The proposal for these reasons is in compliance with the rationale developed by the Court, and would meet the relevant and sufficient grounds in the interests of justice standard.

\section{Conclusion}

This article has asserted that Turkey's counterterrorism efforts may be promoted, if Turkish law recognizes a public safety exception to procedural warnings in police interrogation, and excludes the defense counsel that aim to further terrorism or obstruct justice at the very instance of interrogation.

The former proposal implies that Turkish courts should abandon their shallow understanding of the warning requirement, and should instead make a profound balancing analysis between individual and social interests at stake. They must acknowledge that the warning requirement is not absolute, and emergency circumstances may justify abandoning the rule for a short period of time. The U.S. Supreme Court and ECtHR judgments may lead the way in public safety/compelling reasons exception. Turkish law may follow them through a Constitutional Court judgment revisiting the precedents on the right to a fair trial and illegally obtained evidence, or a legislation that amends the Criminal Procedure Code accordingly.

The latter proposal implies that in cases when a state needs to take a swift action to protect the administration of justice and counterterrorism efforts, its determination could be honored via a judicial decision based on reasonable suspicion. This is the case with dishonest and unethical lawyers who aim to coerce a suspect or facilitate information exchange between a terrorist organization and a suspect or between suspects. An exclusion order may be issued by a magistrate judge to frustrate such attempts. This suggestion reflects society's expectation of virtue and professional responsibility from lawyers.

The proposals involve restrictions that may bring about serious infringements on the right to a fair trial if state agents disregard necessary safeguards. Law enforcement officials must bear in mind that the public safety exception is valid only in exceptional emergency circumstances, in which other people's life, liberty and physical integrity will be jeopardized if the police wait to read procedural warnings or call for a lawyer. Immediately after an urgent need is over, the suspect must be reminded of his procedural 
rights and a lawyer must be provided in his defense. In addition, officials must demonstrate a reasonable basis, supported by intelligence information and their professional experience, to file a request for an exclusion order. Any claims based on personal bias would be unacceptable. In case a lawyer is excluded, no interrogation should be conducted until a court-appointed lawyer arrives at the interrogation room.

It's one thing to make a law, it's another thing to apply it justly. The fair and proper application of these laws depends on a system that is comprised of virtuous and high minded professionals who regard the principle of the rule of law as the supreme value. Therefore, if Turkey intends to adopt the proposed rules, it may have to restructure the government bureaucracy.

Acknowledgement: Profound gratitude to my doctoral dissertation adviser Prof. Daniel J. Capra and committee members Prof. Deborah W. Denno and Judge Ethan Greenberg for their genuine support and invaluable comments.

\footnotetext{
Peer-review: Externally peer-reviewed.

Conflict of Interest: The author has no conflict of interest to declare.

Grant Support: The author declared that this study has received no financial support.

Hakem Değerlendirmesi: Dış bağımsız.

Çıkar Çatışması: Yazar çıkar çatışması bildirmemiştir.

Finansal Destek: Yazar bu çalışma için finansal destek almadığını beyan etmiştir.
}

\section{References/Kaynakça}

Arizona v. Mauro, 481 U.S. 520 (1987).

Avukatlık Kanunu [Advocacy Code] 1136 A.K. § 6 (1969).

Barak, A. (2012). Proportionality: constitutional rights and their limitations. New York, United States: Cambridge University Press.

AYM 14.6.2017 E: 2017/24 K: 2017/112.

AYM 24.7.2019 E: 2018/73 K: 2019/65.

AYM 27.12.2018 E: 2018/153 K: 2018/119.

AYM 07.09.2016 E: 2016/124 K: 2016/155.

AYM 01.11.2017 E: 2017/142 K: 2017/150.

Barkhuysen, T., Emmerik, van M., Jansen, O. \& Fedorova, M. (2018). Right to a fair trial (Article 6). In Pieter van Dijk, Fried van Hoof, Arjen van Rijn \& Leo Zwaak (Eds.), Theory and practice of the European Convention on Human Rights (pp. 497-655). Cambridge, United Kingdom: Intersentia.

Schlink, B. (2012). Proportionality (1). In Michel Rosenfeld \& András Sajó (Eds.), The Oxford handbook of comparative constitutional law (pp.718-738). Oxford, United Kingdom: Oxford University Press.

Beckwith v. United States, 425 U.S. 341 (1976). 
Case of Borg v. Malta (App. no. 37537/13) Strasbourg 19 February 2016.

Case of Croissant v. Germany (App. no. 13611/88) Strasbourg 25 September 1992.

Case of Deweer v. Belgium (App. no. 6903/75) Strasbourg 27 February 1980.

Case of Eckle v. Germany (App. no. 8130/78) Strasbourg 15 July 1982.

Case of Martin v. Estonia (App. no. 35985/09) Strasbourg 30 May 2013.

Case of Mayzit v. Russia (App. no. 63378/00) Strasbourg 20 January 2005.

Case of McFarlane v. Ireland (App. no. 31333/06) Strasbourg 10 September 2010.

Case of Pishchalnikov v. Russia (App. no. 7025/04) Strasbourg 24 September 2009.

Case of Popov v. Russia (App. no. 26853/04) Strasbourg 13 July 2006.

Case of Zagorodniy v. Ukraine (App. no. 27004/06) Strasbourg 24 November 2011.

Centel, N. \& Zafer, H. (2013). Ceza muhakemesi hukuku (10 $0^{\text {th }}$ ed.) [Criminal procedure law]. Istanbul, Turkey: Beta Yayıncilık.

Ceza Kanunu [Penal Code] 5237 T.C.K. § II/3, 4 (2004).

Ceza Muhakemesi Kanunu [Criminal Procedure Code] 5271 C.M.K. § 5, 6 (2004).

CoE. (2020a, January 2). Chart of signatures and ratifications of Treaty 005. Retrieved from https://www.coe. int/en/web/conventions/full-list/-/conventions/treaty/005/signatures.

CoE. (2020b, January 2). Complete list of the Council of Europe's treaties. Retrieved from https://www.coe.int/ en/web/conventions/full-list.

CoE. (2019a). Details of Treaty No.005. Retrieved from https://www.coe.int/en/web/conventions/full-list/-/ conventions/treaty/005.

CoE. (2013, October 2). European Convention on Human Rights. Retrieved from https://www.echr.coe.int/ Documents/Convention_ENG.pdf.

CoE. (2019b). European Court of Human Rights. Retrieved from http://www.coe.int/en/web/tirana/europeancourt-of-human-rights.

C.G.K. 19.12.1994 E. 1994/6-322 K. 1994/343.

C.G.K. 24.10.1995 E.1995/6-238 K. 1995/305.

Devlet İstihbarat Hizmetleri ve Milli İstihbarat Teşkilatı Kanunu [The Statute on State Intelligence Services and the National Intelligence Organization] 6189 M.I.T.K. § 1 (1983).

Dvorski v. Croatia (App. no. 25703/11) ECHR 2015, 405.

Edwards v. Arizona, 451 U.S. 477 (1981).

Ekinci, H. \& Sağlam, M. (2015). 66 soruda bireysel başvuru (2 $2^{\text {nd }}$ ed., extended) [Individual applications in 66 questions]. Ankara, Turkey: Anayasa Mahkemesi Yayınları.

Escobedo v. Illinois, 378 U.S. 478 (1964).

Gözler, K. (2000). Türk anayasa hukuku (1st ed.) [Turkish constitutional law]. Bursa, Turkey: Ekin Kitabevi Yayınlar1.

HRW. (2000). Preventing torture. Retrieved from https://www.hrw.org/reports/2000/turkey2/Turk009-01.htm.

HRW. (2019). Türkiye'de avukatlar ve adil yargılanma hakkı saldırı altında [Lawyers and the right to a fair trial are under attack in Turkey]. Retrieved from https://www.hrw.org/sites/default/files/report_pdf/turkey0419turk_ web.pdf.

Ibrahim and Others v. the United Kingdom (App. nos. 50541/08, 50571/08, 50573/08 and 40351/092016) ECHR 2016.

Jandarma Teşkilat, Görev ve Yetkileri Kanunu [The Statute on the Organization, Duties and Authorities of the Gendarmerie], 2803 J.T.K. § 6 (1983).

Klatt, M. \& Meister, M. (2012). The constitutional structure of proportionality. Oxford, United Kingdom: Oxford University Press. 
LaFave, W. R., Israel, J. H., King, N. J. \& Kerr, O. S. (2015). Criminal procedure V.2. Minnesota, United States: West Academic Publishing.

Meftah and others v. France (App. nos. 32911/96, 35237/97 and 34595/97) ECHR 2002-VII, 265.

Metin, Y. (2002). Ölçülülük ilkesi: Karşılaştırmalı bir anayasa hukuku incelemesi (1st ed.) [The principle of proportionality: A comparative constitutional law analysis]. Ankara, Turkey: Seçkin Yayıncılık.

MFA. (2011). Council of Europe. Retrieved from http://www.mfa.gov.tr/council-of-europe.en.mfa.

Miranda v. Arizona, 384 U.S. 436 (1966).

Moran v. Burbine, 475 U.S. 412 (1986).

New York v. Quarles, 467 U.S. 649 (1984).

Oehmichen, A. (2009). Terrorism and anti-terror legislation, the terrorised legislator?: A comparison of counterterror legislation and its implications on human rights in the legal systems of the United Kingdom, Spain, Germany and France. Antwerp: Intersentia.

Orozco v. Texas, 394 U.S. 324 (1969).

Öztürk, B., Tezcan, D., Erdem, M.R., Sırma, Ö., Saygılar Kırıt, Y. F., Özaydın, Ö., Alan Akcan, E., \& Erden, E. (2015). Nazari ve uygulamall ceza muhakemesi hukuku ( $9^{\text {th }}$ ed.) [Criminal procedure law]. Ankara, Turkey: Seçkin Yayıncılık.

PACE. (1992, June 30). Situation of human rights in Turkey, Eur. Parl. Ass. Res. 985 (June 30, 1992). Retrieved from http://assembly.coe.int/nw/xml/XRef/Xref-XML2HTML-en.asp?fileid=16396\&lang=en.

Polis Vazife ve Salahiyet Kanunu [The Statute on Duties and Authorities of the Police] 2559 P.V.S.K. § Supp. 7-2 (1934).

Rhode Island v. Innis, 446 U.S. 291 (1980).

Saltzburg, S. A. \& Capra, D. J. (2014). American criminal procedure: cases and commentary. Minnesota, United States: West Academic Publishing.

Salduz v. Turkey (App.no. 36391/02) ECHR 2008-V, 59.

Saunders v. the United Kingdom (App. no. 19187/91) ECHR 1996-VI, 2044.

Soyaslan, D. (2016). Ceza muhakemesi hukuku (6 th $^{\text {ed.) }}$ [Criminal procedure law]. Ankara, Turkey: Yetkin Hukuk Yayınlar1.

Strafprozeßordnung [Criminal Procedure Code] StPO § 137, 138a (1987).

Tanör, B. \& Yüzbaşığlu, N. (2001). 1982 Anayasasına göre Türk anayasa hukuku ( $2^{\text {nd }}$ ed.) [Turkish constitutional law in respect of the Constitution of 1982]. Istanbul, Turkey: YKY Yayıncilik.

T.C. Anayasas1 [Turkish Constitution] 2709 AY § 2 (1982).

The Arrested Lawyers Initiative \& CNF (2020). Mass prosecution of lawyers in turkey: unjust arrests \& convictions (2016-2020). Rome, Italy: Infocarcere LTD Limited Cooperative Company.

Retrieved from https://arrestedlawyers.files.wordpress.com/2020/04/rapporto-febbraio-2020delle28099associazione-arrested-lawyers-initiative-sulla-persecuzione-di-massa-degli-avvocati-in-turchiainglese.pdf.

U.S. Constitution Amend. V (1787).

Weisselberg, C. D. (2017). Exporting and importing Miranda. BUL Rev., 97, 1235-1291. Retrived from https:// heinonline.org/HOL/LandingPage?handle=hein.journals/bulr97\&div=33\&id=\&page $=$.

Wheat v. United States, 486 U.S. 153 (1988).

Yenisey, F. (2015). Kolluk hukuku (2nd ed.) [The law of law enforcement agencies]. Istanbul, Turkey: Beta Yayincilik.

Yenisey, F. \& Nuhoğlu, A. (2015). Ceza muhakemesi hukuku (1st ed.) [Criminal procedure law]. Ankara, Turkey: Seçkin Yayıncılık. 